\title{
Psychological Empowerment as a Predictor of Work Engagement among Officers of Nigerian Immigration Services
}

\author{
Arogundade, Odunayo. $\mathrm{T}^{1}$., Arogundade, Ayodeji. B ${ }^{2}$ And Odoh, Ellis ${ }^{1}$ \\ ${ }^{1}$ Department of Behavioural Studies, Redeemer's University, Ede, Osun State, Nigeria. \\ ${ }^{2}$ Business Division, Lewis-Clark State College, Lewiston, Idaho, USA.
}

\begin{abstract}
This study examines the influence of psychological empowerment on work engagement among officers of Nigerian immigration services. A survey research design was adopted and data were collected from two hundred and Twenty- five (225) participants (M=147, F=78) using a battery of psychological test consisting of Psychological Empowerment Scale (PES) and the Utrecht Work Engagement Scale (UWES-9). The data were analysed using percentages and multiple regression analysis to test the hypothesis. The results show that all the dimensions of psychological empowerment jointly accounted for $25 \%$ of the variance in employees' work engagement. Furthermore, the various dimensions of psychological empowerment contributed differently to the variance in employees' work engagement. The Beta calculations showed that the highest variation was explained by self-determination $(\beta=0.36)$, followed by meaningfulness $(\beta=0.20)$, Competence $(\beta=$ $0.16)$ and the lowest was explained by impact $(\beta=-0.01)$. The findings confirm the benefits of psychologically empowering workers to enhance positive work behaviour such as work engagement.
\end{abstract}

Keywords: psychological empowerment. work engagement, immigration services

\section{INTRODUCTION}

The $21^{\text {st }}$ century Nigeria has witnessed a lot of changes ranging from economic meltdown, recession, re-engineering, downsizing, mergers and layoffs because of globalization (Arogunndade \& Arogundade, 2015). The recent economic pressures caused by the global economic meltdown has brought about drastic fall in the prices of crude oil which is the major source of income for the Nigerian government; sabotage of public utilities, privatization of public enterprises, consolidation of financial sectors, bureaucratic corruption, increased government deregulations policies and various religious violence especially in the North-eastern part of the country have resulted into producing more discontented and disengaged workers in the country. Especially, among the civil servants which is the greatest asset of the country in her quest for sustainable development as well as the instrument through which government; federal, state or local manage development (Olu-Adeyemi, 2009) have constantly experience increased level of anxiety coupled with feelings of uncertainty due to frequent cases of delayed payment of salary and high level of retrenchment or turnover of workers. Consequently, there is a sharp decrease in performance outcome and level of productivity.

In view of the foregoing, there is need to seek for remedy to this poor work attitude and negative performance by promoting the attributes of engaged employees which include: a positive, fulfilling, affectivemotivational state of work-related well-being (Macey \& Schneider, 2008). Work engagement has been defined as "a positive, fulfilling, work-related state of mind that is characterized by vigor, dedication, and absorption" (Schaufeli, Salanova, Gonzalez-Romá, \& Bakker, 2002). According to Schaufeli \& Salanova (2007), highly engaged workers are full of vitality, they feel they are glued to their work, and are better able to deal with job demands. Engagement is neither a momentary nor a specific state, but refers to a more persistent and pervasive affective-cognitive state that is not focused on any object, event, individual, or behavior (Shimazu, Schaufeli, Kosugi, Suzuki, Nashiwa, Kato, Sakamoto, Irimajiri, Amano, Hirohata, Goto, Kitaoka-Higashiguchi, 2008). Vigour is characterized by high energy levels and mental resilience while working. Dedication refers to being strongly involved in one's work and experiencing a sense of significance, enthusiasm, and challenge. Absorption entails being fully concentrated and happily engulfed in one's work, whereby time passes quickly and one has difficulties with separating oneself from work. In short, engaged employees have high levels of energy and are enthusiastic about their work, they are often fully immersed in their work so that time flies (May, Gilson, \& Harter, 2004). Bakker and Schaufeli, (2008) hold that engaged employees are highly energetic, selfefficacious individuals who exercise influence over events that affect their lives. Engaged employees thus, create their own positive feedback, in terms of appreciation, recognition, and success because of their positive attitude and activity level. Although, engaged employees sometimes get tired after a long day of hard work, but, they describe the tiredness as rather a pleasant state because it is associated with positive accomplishments. 
Unlike workaholics, engaged employees do not work hard because of a strong and irresistible inner drive, but because to them working is fun (Gorgievski, Bakker, \& Schaufeli, 2010).

\section{PSYCHOLOGICAL EMPOWERMENT AND WORK ENGAGEMENT}

Recently, many empirical studies have shown that work engagement has positive relationship with organizational performance (Saif \& Saleh, 2003; Andreassen, Ursin, \& Eriksen, 2007; Vallerand, 2008; Geetha \& Mampilly, 2014). It was revealed in one of their studies that engagement has positive effect not just on individual performance of employees but also on group task performance. They found that engaging employees improves service climate, and then enhances customer-assessed employee performance. Although, both work engagement and psychological empowerment represent intrinsic motivation, there are only a few empirical researches that examine how these two construct are related.

Greco, Laschinger and Wong (2006) found in one study that leaders empowering behaviors (supervisor support or organizational support) fosters psychological empowerment and thereby producing engaged workers. In a related study of Stander and Rothmann (2010), they empirically examined the relationship between work engagement and psychological empowerment, and found that psychological empowerment predicts work engagement.

Accordingly, May, Gilson and Harter (2004) confirm that psychological meaningfulness, psychological safety and psychological availability Predict employee engagement. Another related study by Deci, Eghrari, Patrick and Leone, (1994) found that psychological empowerment has been shown to lead to greater engagement in an initially uninteresting activity and increased positive feelings towards the activity. Moreover, Williams and Deci (1996) found that supervisory autonomy support helped medical student's development of psychological values and fostered autonomy supportive behaviour towards patients. In the work domain, Deci, Conneli and Ryan (1989) trained managers to be autonomy supportive with their subordinates and found that psychological empowerment later produced trust in the organization, and had positive outcomes of engagement. Deci (1994) in his study of work autonomy and work engagement found out that autonomy support or psychological support has a great role to play in the behaviour of workers within an organization. It was shown that work autonomy (less supervision) only leads to greater engagement in initially uninteresting work activities.

Finally, Geetha \& Mampilly (2014), in a study based on primary data collected from one hundred and one (101) employees working in three (3) service organizations in Central Kerala in 2014, found that a significant positive association exists between psychological empowerment and employee engagement. Further analysis showed that all the dimensions of psychological empowerment, other than self-determination were predictors of employee engagement.

Although, all the studies reviewed show that psychological empowerment and work engagement are positive work behaviour and performances outcomes, but none has taken Nigerian Civil servants into consideration, especially the officers of the Nigerian Immigration Service.

Thus, this present study is designed to find out the influence of the various dimensions of psychological empowerment (meaningfulness, competence, self-determination and impact) on employees' work engagement of the officers of the Nigerian Immigration Service.

$\mathrm{H}_{1}$. The dimensions of psychological empowerment (meaningfulness, competence, choice and impact) will significantly predict work engagement among officers of Nigerian Immigration Services.

Participants and Procedure.

\section{METHOD}

This study is a non-experimental and quantitative study that utilized two psychological tests to examine the influence of psychological empowerment on the work engagement of selected immigration officers in Lagos, Nigeria. The participants were two hundred and forty-one (241) officers randomly selected from five (5) immigration offices in Lagos, Nigeria, namely: Ikoyi Command Office, Ikoyi Passport Office, Festac Passport Office, Ikeja Passport Office, and Ikeja Zone-A Office.

\section{Instruments}

A battery of psychological test consisting of Psychological Empowerment Scale (PES) and the Utrecht Work Engagement Scale (UWES-9) were used for data collection.

\section{Psychological Empowerment Scale (PES)}

This scale was developed by Spreitzer (1995) to measure level of psychological empowerment. It is a twelve (12) item test with four-sub-dimensional Scale namely: meaning, competence, self-determination and impact. Examples of items include "The work I do is very important to me," "I am confident about my ability to do my job," "I have significant autonomy in determining how I do my job," and "my impact on what happen in my department is large". A higher score in this type of test indicates more psychological empowerment. 
Furthermore, Spreitzer (1995) reported coefficient alpha values ranging from .81 to .87 for meaning, .76 to .84 for competence, .79 to .85 for self-determination, .83 to .88 for impact and .72 for overall empowerment.

\section{Utrecht Work Engagement Scale (UWES-9)}

Schaufeli \& Salanova (2002) developed Utrecht Work Engagement Scale-9 (UWES-9) to measure work engagement. It is a nine- item scale comprising three dimensions of work engagement namely: Vigour, Dedication, and Absorption. Example of items include;" At my work, I feel bursting with energy." (Vigour)," I am enthusiastic about my job." (Dedication)," time flies when I am working." (Absorption). The UWES is scored in a 6-point Likert-type scale anchored from never (0) to always (6).

Schaufeli, et. al (2006) established the psychometric properties. They reported coefficient alpha values ranging from .41 to .66 for the scale while the sub- scales of vigour dimension have a Cronbach's $\alpha$ of .76; dedication has .79, and absorption has .74. The nine (9) items yielded a Cronbach's $\alpha$ of .91

\section{Data Analyses}

The data gathered using the psychological tests were coded and analysed with the Statistical Package for the Social Sciences (SPSS) version 20 on a personal computer. Specifically, percentages and multiple regression analysis were used to analysed the data.

IV. THE RESULTS

Table 1: Social Demographic Characteristics of the Participants

\begin{tabular}{|l|l|c|c|c|c|}
\hline \multicolumn{2}{|c|}{ Variables } & Frequency & \% & $\bar{X}$ & SD \\
\hline \multirow{3}{*}{ Gender } & Male & 147 & 65.33 & 40.39 & 8.06 \\
\cline { 2 - 6 } & Female & 78 & 34.67 & 41.36 & 7.11 \\
\hline \multirow{4}{*}{ Age } & $21-30$ years & 13 & 5.78 & 39.23 & 5.07 \\
\cline { 2 - 6 } & $31-40 y e a r s$ & 51 & 22.67 & 39.92 & 6.77 \\
\cline { 2 - 6 } & 41-50years & 81 & 36 & 41.44 & 8.77 \\
\cline { 2 - 6 } & 51-60years & 80 & 35.56 & 40.76 & 7.60 \\
\hline \multirow{2}{*}{ Marital Status } & Married & 201 & 89.33 & 41.07 & 7.83 \\
\cline { 2 - 6 } & Single & 24 & 10.67 & 37.83 & 6.34 \\
\hline \multirow{2}{*}{ Level of Officer } & Senior & 169 & 75.11 & 40.94 & 8.05 \\
\cline { 2 - 6 } & Junior & 56 & 24.89 & 40.09 & 6.73 \\
\hline
\end{tabular}

Table1 above shows the socio-demographic attributes of the participants. In terms of the gender of participants, $65.33 \%$ were males and $34.67 \%$ were females, the age range shows that $5.78 \%$ of the participants were within ages $21-30,22.7 \%$ within ages $31-40,36 \%$ within ages $41-50$, while $35.56 \%$ were at least 51 years old. In terms of the marital status of participants, $10.67 \%$ of the participants were single, while $89.33 \%$ were married. Finally, in terms of the rank and status, $75 \%$ of the participants were of senior cadre while $24.89 \%$ were from lower cadre.

\section{The Results of Hypothesis Testing:}

$\mathrm{H}_{1}$. The dimensions of psychological empowerment (meaningfulness, competence, choice and impact) will significantly predict work engagement among officers of Nigerian Immigration Services.

To test the hypothesis, a multiple regression analysis was computed and the result is displayed below:

Table 2: Multiple Regression Model Summary

\begin{tabular}{|c|c|c|c|c|c|c|}
\hline Variable & $\boldsymbol{\beta}$ & $\mathbf{t}$ & $\mathbf{R}$ & $\mathbf{R}^{2}$ & $\mathbf{F}$ & $\mathbf{P}$ \\
\hline Competence & .16 & 2.46 & & & & \\
\hline Self Determination & .36 & 5.34 & & & & \\
\hline Impact & -.01 & -.06 & & & & \\
\hline Meaningfulness & .20 & 3.11 & & & & \\
\hline \multicolumn{3}{|l|}{ Total } & .49 & .25 & 17.64 & $<.05$ \\
\hline
\end{tabular}

Predictor variables: Competence, Self-determination, Impact, Meaningfulness

Dependent variable: Work engagement.

Table 2 shows that the four dimensions of psychological empowerment accounted for $25 \%$ variance in work engagement. However, the various dimensions of psychological empowerment contributed differently to the variance in work engagement. The Beta calculations showed that the highest variation was explained by 
Self-determination $(\beta=0.36)$, followed by meaningfulness $(\beta=0.20)$, Competence $(\beta=0.16)$ and the lowest was explained by Impact $\beta=-0.01)$. Thus, hypothesis one was accepted.

Furthermore, all the dimensions of psychological empowerment except impact has positive relationship with work engagement. This implies that an increase in the dimensions of Self-determination, meaningfulness, and Competence will result in increase in work engagement.

\section{DISCUSSION}

This study examined the influence of the dimensions of psychological empowerment (meaningfulness, competence, choice, and impact) in predicting employees' work engagement among the officers of Nigerian Immigration Services. The findings of the study confirm that the overall dimensions of psychological empowerment accounted for $25 \%$ of the variance in employees' report of work engagement. This implies that the more an organization empowers the workers psychologically, the more they remained engaged to their works.

This finding is in consonance with Greco et. al (2006) who found that leaders empowering behaviours fosters psychological empowerment and thereby producing engaged workers. Other Social analysts also supported the findings that empirically relationship between work engagement and psychological empowerment, and that psychological empowerment predicts work engagement (Stander and Rothmann 2010; May et. al 2004; Deci et.al 1994).

Deci, Conneli and Ryan (1989) reported that managers who empower their subordinates tend to positive outcomes of engagement in the workers. Furthermore, in a related study of Deci (1994) found that autonomy support or psychological support (less supervision) only leads to greater engagement in initially uninteresting work activities.

Finally, Geetha et. al (2014), also supported the findings that in a study from employees working in three (3) service organizations in Central Kerala that a significant positive association exists between psychological empowerment and employee engagement. Further analysis showed that all the dimensions of psychological empowerment, other than self-determination were predictors of employee engagement The conclusion is that psychological empowerment has consistent positive impact performance outcomes which include work engagement (Arogundade et. al., 2015; Saif, \& Saleh, 2013; Baker, Fitzpatrick, and Griffin, 2012; Hossein, Saleh, Iman, \& Jaafar, 2012) in respective of the job or geographical location.

\section{REFERENCES}

[1]. Andreassen, C.S., Ursin, H. \& Eriksen, H.R. (2007), "The relationship between strong motivation to work, workaholism and health", Psychology and Health, 22,615-29.

[2]. Arogundade, O. T \& Arrogundade, A. B. (2015). Psychological empowerment in the work place:

[3]. Implications for Employees Career Satisfaction. North American journal of psychology.

[4]. Baker, S., Fitzpatrick, J., \& Griffin, M. (2012). Empowerment and job satisfaction in associate degree nurse educators. Nursing Education Research, 32 ( 4), 234-239.

[5]. Bakker, A. B., Schaufeli, W. B . (2008). Work engagement: An emerging concept in occupational health psychology. Work and Stress, 22, 187-200.

[6]. Deci, E. L., Eghrari, H., Patrick, B. C., \& Leone, D. R. (1994). Facilitating internalization: The selfdetermination theory perspective. Journal of Personality, 62, 119-142.

[7]. Deci, E.L., \& Ryan, R.M. (2000). The "what" and "why" of goal pursuits: Human needs and the self-determination of behavior. Psychological Inquiry, 11, 227-268.

[8]. Geetha \& Mampilly. (2014). Psychological empowerment as a predictor of Employee Engagement: An empirical attestation. Global business review.

[9]. Gorgievski, M., Bakker, A.B. \& Schaufeli, W.B. (2010), "Work engagement and workaholism: Comparing the self-employed and employees on payroll", Journal of Positive Psychology, 5, 83-86.

[10]. Greco, P., Laschinger, H.K.S., \& Wong, C. (2006). Leader empowering behaviors, staff work empowerment and work engagement/burnout. Nursing Leader - ship, 19 (4), 41-56.

[11]. Hossein, R., Saleh, P., Iman, A, \& Jaafar, A. (2012) An analysis of the empowerment level of employees and it's relation to organizational factors. International Journal of Business and Social Science, 3 (15), 255-263.

[12]. Macey W. H, \& Schneider, B. (2008). The meaning of employee engagement. Industrial and Organizational Psychology. 1, 3-30

[13]. May, D. R., Gilson, R. L. \& Harter, L. M. (2004).The psychological conditions of meaningfulness, safety and availability and the engagement of the human spirit at work. Journal of Occupational \& Organizational Psychology,77, 11-37.

[14]. Oladipo, S.E. (2009). Psychological empowerment and development. Edo journal of counselling. Vol.2(1), pp: 119-126. 
[15]. Olu-Adeyemi, L. (2009), Public administration reform in Nigeria, in R.F Ola \& D.A Tonwe (eds.), Nigerian public administration, Lagos: Amfitop books.

[16]. Saif, N. I., \& Saleh, A. S. (2013). Psychological Empowerment and Job Satisfaction in Jordanian

[17]. Hospitals. International Journal of Humanities and Social Science. Vol. 3, No. 16, pp. 250-257.

[18]. Schaufeli, W. B., \& Bakker, A. B. (2004). Job demands, job resources, and their relationship with burnout and engagement: A multi-sample study. Journal of Organizational Behavior, 25, 293-315.

[19]. Schaufeli, W. B., Bakker, A. B., \& Salanova, M. (2006). The measurement of work engagement with a short questionnaire: A cross-national study. Education and Psychological Measurement, 66, 701-716.

[20]. Schaufeli, W., Salanova, M., Gonzalez-Roma, V., \& Bakker, A. (2002). The measurement of engagement and burnout: A two sample confirmatory factor analytic approach. Journal of Happiness Studies, 3, 71-92.

[21]. Schaufeli, W.B., \& Salanova, M. (2007). Work engagement: An emerging psychological concept and its implications for organizations. In S.W. Gilliland, D.D. Steiner, \& D.P. Skarlicki (Eds.), Research in Social Issues in Management (Volume 5): Managing Social and Ethical Issues in Organizations. Greenwich, CT: Information Age Publishers.

[22]. Shimazu, A., Schaufeli, W. B., Kosugi, S., Suzuki, A., Nashiwa, H., Kato, A., Sakamoto, M., Irimajiri, H., Amano, S., Hirohata, K., Goto, R., \& Kitaoka-Higashiguchi, K. (2008). Work engagement in Japan: Development and validation of the Japanese version of the Utrecht Engagement Scale. Journal of Applied Psychology: An International Review, 57, 510-523.

[23]. Spreitzer, G. M. (1995). Psychological empowerment in the workplace: Dimensions, measurement, and validation. Academy of Management Journal, 38, 1142-1465.

[24]. Stander, M. W. \& Rothmann, S. (2010). Psychological empowerment, job insecurity and employee engagement. South Africa Journal of Industrial Psychology 36(1), 1-8.

[25]. Vallerand, R.J. (2008), “On the psychology of passion: in search of what makes people's lives most worth living”, Canadian Psychology ,49, 1-13.

[26]. Williams, G. C., \& Deci, E. L. (1996). Internalization of biopsychosocial values by medical students: A test of self-determination theory. Journal of Personality and Social Psychology, 70 , 767-779. 